\title{
The regional distribution characteristics of aerosol optical depth over the Tibetan Plateau
}

\author{
C. $\mathbf{X u}^{1,2,3, a}$, Y. M. Ma ${ }^{1,2,3, a}$, C. You ${ }^{1,2}$, and Z. K. Zhu ${ }^{1,2,3}$ \\ ${ }^{1}$ Key Laboratory of Tibetan Environment Changes and Land Surface Processes, Institute of Tibetan Plateau Research, \\ CAS Center for Excellence in Tibetan Plateau Earth Sciences, Chinese Academy of Sciences, Beijing 100101, China \\ ${ }^{2}$ University of Chinese Academy of Sciences, Beijing 100049, China \\ ${ }^{3}$ Qomolangma Station for Atmospheric Environmental Observation and Research, Chinese Academy of Sciences, \\ Dingri 858200, Tibet, China \\ a now at: Institute of Tibetan Plateau Research, CAS Center for Excellence in Tibetan Plateau Earth Sciences, Chinese \\ Academy of Sciences, Beijing, China
}

Correspondence to: Y. M. Ma (ymma@itpcas.ac.cn) and C.Xu (xuchao@itpcas.ac.cn)

Received: 4 May 2015 - Published in Atmos. Chem. Phys. Discuss.: 11 June 2015

Revised: 17 October 2015 - Accepted: 23 October 2015 - Published: 30 October 2015

\begin{abstract}
The Tibetan Plateau (TP) is representative of typical clean atmospheric conditions. Aerosol optical depth (AOD) retrieved by the Multi-angle Imaging SpectroRadiometer (MISR) is higher over Qaidam Basin than the rest of the TP throughout the year. Different monthly variation patterns of AOD are observed over the southern and northern TP, whereby the aerosol load is usually higher in the northern TP than in the southern part. The aerosol load over the northern part increases from April to June, peaking in May. The maximum concentration of aerosols over the southern TP occurs in July. Aerosols appear to be more easily transported to the main body of the TP across the northern edge rather than the southern edge. This is maybe partly because the altitude is lower at the northern edge than that of the Himalayas located along the southern edge of the TP. Three-dimensional distributions of dust, polluted dust, polluted continental aerosol and smoke are also investigated, based on Cloud-Aerosol Lidar and Infrared Pathfinder Satellite Observation (CALIPSO) data. Dust is found to be the most prominent aerosol type on the TP, and other types of aerosols affect the atmospheric environment slightly. A dividing line of higher dust occurrence in the northern TP and lower dust occurrence in the southern TP can be observed clearly at an altitude of $6-8 \mathrm{~km}$ above sea level, especially in spring and summer. This demarcation appears around 33$35^{\circ} \mathrm{N}$ in the middle of the plateau, and it is possibly associated with the high-altitude terrain in the same geographic lo-
\end{abstract}

cation. Comparisons of CALIPSO and MISR data show that the vertical dust occurrences are consistent with the spatial patterns of AOD. The different seasonal variation patterns between the northern and southern TP are primarily driven by atmospheric circulation, and are also related to the emission characteristics over the surrounding regions.

\section{Introduction}

The Tibetan Plateau (TP), located in central eastern Eurasia, is the most prominent and complex terrain feature on the Earth. It has the world's highest average elevation (about $4000 \mathrm{~m}$ ), with some surface features even reaching into the mid-troposphere (Fig. 1). The TP is surrounded by several deserts, including the Taklamakan Desert in the Tarim Basin, Gobi Desert and the deserts in southwest Asia and the Middle East. The Indo-Gangetic Plain is located to the south of the TP, with high aerosol loading (Gautam et al., 2011). Several mountains are located on the TP, including the Himalayas, Gangdise, Nyainqêntanglha, Tanggula and Kunlun mountains. The elevation differences of these mountains are at least $500 \mathrm{~m}$ and usually $1000 \mathrm{~m}$ or even more compared with the surrounding areas. Due to its topographic characteristics, the TP surface absorbs high quantities of solar radiation with corresponding impacts on surface heat or water fluxes (Ma et al., 2014a, b). The east Asian monsoon and the 


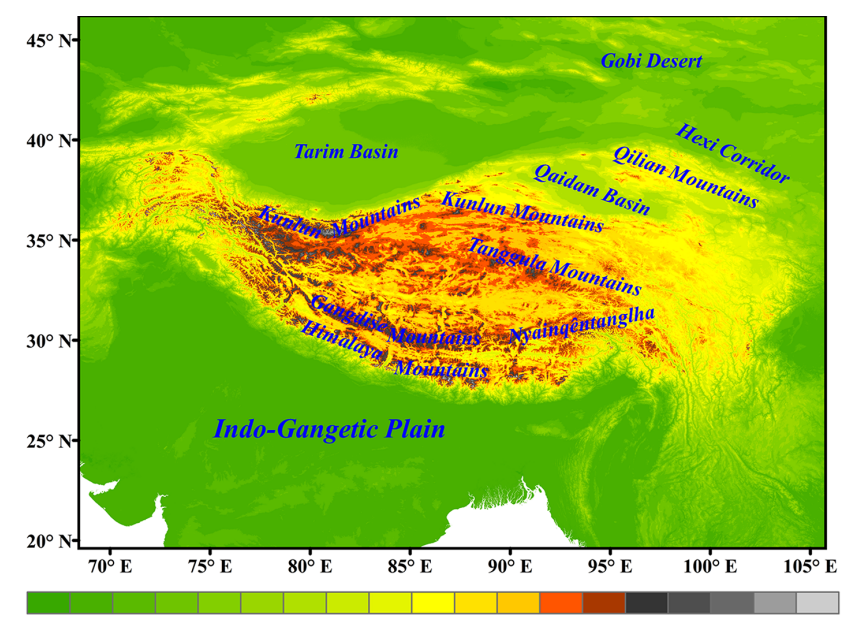

$0 \quad 500 \quad 10001500 \quad 200025003000350040004500475050005250 \quad 55005750600062506500$

Figure 1. The topography (in meters) of the Tibetan Plateau and main mountain ranges on the Tibetan Plateau.

eastern part of the south Asian monsoon systems are mainly controlled by the thermal forcing of the TP (Wu et al., 2007, 2012).

Many studies have focused on environmental and climate change over the TP (Xu et al., 2009; Ma et al., 2011; Lin et al., 2012; Yao et al., 2012; Sheng et al., 2013), and the TP environment is greatly affected by natural and anthropogenic aerosols from the surrounding regions (Z. Liu et al., 2008; Bucci et al., 2014; Cong et al., 2015). Therefore, studying tropospheric aerosols and their effects on the TP is of great importance (King et al., 1999; Kaufman et al., 2002; Li et al., 2011). Vernier et al. (2011) reported the presence of an aerosol layer at the tropopause level above Asia during the monsoon season. The Taklamakan and Gobi deserts are two major dust sources with long-range transport mainly occurring in spring (D. Liu et al., 2008). Summertime Tibetan airborne dust plumes were detected from the Cloud-Aerosol Lidar and Infrared Pathfinder Satellite Observations (CALIPSO) satellite (Huang et al., 2007), and Xia et al. (2008) suggested that the aerosol load in summer over the TP was mainly associated with the Taklamakan Desert. Dust above the TP appears to be largely related to source regions to the north and on the eastern part of the TP $(\mathrm{Z}$. Liu et al., 2008). The impact of aerosols above and around the TP during pre-monsoon season was also investigated; however, a strong elevated heating which could influence largescale monsoonal circulations was not found (Kuhlmann and Quaas, 2010). Atmospheric brown clouds over south Asia, resulting from biomass burning and fossil fuel consumption, are recognized as a serious environmental problem (Ramanathan et al., 2005). These carbonaceous aerosols lead to a large reduction of solar radiation at the surface, an increase of solar heating in the atmosphere and a weaker hydrological cycle (Ramanathan et al., 2001). Anthropogenic emissions from strong pollution events can occasionally be trans- ported to the central TP by prevailing southwesterly winds (Xia et al., 2011). The high altitudes of the Himalayas appear to block most BC particles intruding into the TP, but the Yarlung Tsangpo River valley serves as a "leak" by which contaminants can reach the southeast TP (Cao et al., 2010). Results from precipitation isotope observations revealed that the northward maximum extent of the southwest monsoon over the Tibetan Plateau is located around $34-35^{\circ} \mathrm{N}$ (Tian et al., 2007). The southern and northern TP are under the control of different climate systems during the monsoon season (Yao et al., 2013). Some previous studies have indicated that the southern and northern TP possibly present different variations in aerosol properties, e.g., different temporal variations in dust storm records (Wu et al., 2013). However, the mechanisms of those differences still need further study.

Although the aerosol load is relatively low, aerosols over the TP have unique characteristics. In this study, the seasonal variations and spatial distributions of aerosols over the TP are presented based on the Multi-angle Imaging SpectroRadiometer (MISR) data. The seasonal vertical distributions of dust, polluted dust, polluted continental aerosol and smoke are also investigated using CALIPSO data. This study might indicate that a natural demarcation of aerosols between the northern and southern TP exists in the middle of the plateau. In addition to that, the spatial patterns of aerosol loading are consistent with the vertical distributions of aerosols. We preliminarily propose the possible mechanisms for the aerosol distributions.

\section{Data and methodology}

The MISR was successfully launched into Sun-synchronous polar orbit aboard Terra, NASA's first Earth Observing System (EOS) spacecraft, on 18 December 1999. Viewing the sunlit Earth simultaneously at nine widely spaced angles, MISR provides radiometrically and geometrically calibrated images in four spectral bands at each of the angles. MISR observes the entire Earth about once per week. The spatial resolution of the operational MISR aerosol retrieval algorithm is $17.6 \mathrm{~km} \times 17.6 \mathrm{~km}$. The retrieval region has $16 \times 16 \mathrm{sub}-$ regions, and each subregion covers a $1.1 \mathrm{~km} \times 1.1 \mathrm{~km}$ area. One of the key issues for satellite aerosol products is cloud contamination, including MISR data (Kahn et al., 2010). Three cloud-mask products are used in the aerosol preprocessing. The MISR standard products include three separate MISR-derived cloud masks: Radiometric Camera-bycamera Cloud Mask (RCCM) (Yang et al., 2007), StereoDerived Cloud Mask (SDCM) (Moroney et al., 2002) and Angular-Signature Cloud Mask (ASCM) (Di Girolamo and Wilson, 2003). Based on collocated MISR and Moderate Resolution Imaging Spectroradiometer (MODIS) data, Shi et al. (2014) suggested that cloud contamination existed in both over-water and over-land MISR AOD data, with heavier cloud contamination occurring over the high-latitude south- 
ern hemispheric oceans. MISR aerosol retrievals have been evaluated by many studies (Martonchik et al., 2004; Kahn, 2005; Witek et al., 2013). The accuracy of MISR AOD was much better than MODIS AOD over land (Abdou et al., 2005). Xia et al. (2008) made comparisons of MISR AOD with ground-based hazemeter measurements made at Lhasa and Haibei stations on the TP, which showed a high correlation coefficient and a low root-mean-square error. The Level 3 aerosol product is a summary of the Level 2 aerosol product. In this study, daily Level 3 MISR aerosol data from March 2000 to December 2014 are used to investigate the aerosol spatial distribution, and the spatial resolution of MISR data is $0.5^{\circ} \times 0.5^{\circ}$.

Monthly variations of AOD at $558 \mathrm{~nm}$ are analyzed over the TP. If there was only one satellite observation for a month then this grid value in that particular month was excluded for that year, since there would be too few observations to represent the monthly average. The monthly means that represent the aerosol long-term distribution are calculated by averaging the observation data for that month in each year. To analyze aerosol zonal average, only aerosol retrievals over the $\mathrm{TP}\left(27-40^{\circ} \mathrm{N}, 75-105^{\circ} \mathrm{E}\right)$ at elevations higher than $3000 \mathrm{~m}$ are used. In this study, the northern part of the TP is defined as the region north of $33-34^{\circ} \mathrm{N}$, and the southern part of the $\mathrm{TP}$ is defined as the region south of $33-34^{\circ} \mathrm{N}$. The reason for selecting $33-34^{\circ} \mathrm{N}$ is based on the distributions of aerosols, which appear to show different patterns to the north and south of this latitude.

The Cloud-Aerosol Lidar and Infrared Pathfinder Satellite Observation (CALIPSO) satellite provides new insight into clouds and atmospheric aerosols (Winker et al., 2007, 2010). The CALIPSO satellite was launched into a Sunsynchronous orbit on 28 April 2006, with a 16-day repeating cycle. The lidar Level 3 aerosol product is a quality-screened aggregation of Level 2 aerosol profile data. A series of filters are designed to eliminate samples and layers that were detected or classified with very low confidence or that have untrustworthy extinction retrievals (Winker et al., 2013). The CALIPSO version 1.00 and version 1.30 Level 3 aerosol profile data from March 2007 to February 2015 are used in this study. Nighttime all-sky data are used, because the instrument is more sensitive during nighttime than daytime without solar background illumination (Winker et al., 2013). The spatial resolution of Level 3 data is $5^{\circ} \times 2^{\circ}$ (longitude-latitude), and the vertical resolution is $60 \mathrm{~m}$ observed from -0.5 to $12 \mathrm{~km}$ above sea level (a.s.l.; all altitudes hereafter also refer to a.s.l. where no other specification is given) in the troposphere. The primary variable of aerosol type is used, and this variable counts the number of aerosol samples of each aerosol type for each latitude/longitude/altitude grid cell. Six aerosol types including clean marine, dust, polluted continental aerosol, clean continental aerosol, polluted dust, and smoke are classified. From the data product descriptions, the composition of six aerosol types can be known. Clean marine is a hygroscopic aerosol that consists primarily of sea salt $(\mathrm{NaCl})$. Dust is mostly mineral soil. Polluted continental aerosol is background aerosol with a substantial fraction of urban pollution. Clean continental aerosol is a lightly loaded aerosol consisting of sulfates $\left(\mathrm{SO}_{4}^{2-}\right)$, nitrates $\left(\mathrm{NO}_{3}^{-}\right)$, organic carbon $(\mathrm{OC})$ or ammonium $\left(\mathrm{NH}_{4}^{+}\right)$. Polluted dust is a mixture of desert dust and smoke or urban pollution. Smoke aerosol consists primarily of soot and OC. Mixtures of two aerosol types are not assigned to one aerosol sample. Dust, polluted dust, polluted continental aerosol and smoke possibly influence the TP (Kuhlmann and Quaas, 2010). The aerosol samples for these major types in each season were calculated by accumulating the detected samples for the season in each latitude/longitude/altitude grid cell. The multiyear aerosol samples for each season are obtained by averaging across multiple years. The classification algorithms use the integrated attenuated backscatter measurements, the volume depolarization ratio measurements, surface type and layer altitude to determine aerosol type (Omar et al., 2009). The similarity of the optical properties between polluted continental aerosol and smoke makes the classification of these two aerosol types difficult (Omar et al., 2009). Mielonen et al. (2009) made comparisons of Cloud-Aerosol Lidar with Orthogonal Polarization (CALIOP) Level 2 aerosol types and those derived from Aerosol Robotic Network (AERONET) inversion data. The results revealed the greatest agreement for the dust type (91\% of the cases), moderate agreement for the polluted dust type (53\% of the cases), and poorer agreement for smoke (37\% of the cases) and for polluted and clean continental aerosol combined (22\% of the cases). Burton et al. (2013) made comparisons of aerosol types between CALIPSO and airborne High Spectral Resolution Lidar, which showed the best agreement for desert dust (80\% of the cases) and marine aerosols (62\% of the cases), moderate agreement for the polluted continental aerosols $(53 \%$ of the cases), but relatively poor agreement for polluted dust (35\% of the cases) and smoke (13\% of the cases). Although previous studies showed different results of quantitative validations, these research studies indicated that the classifications for dust aerosols were reliable. Moreover, it is necessary to state that the classifications of smoke aerosols presented here are subject to large uncertainty. There are uncertainties associated with incorrect aerosol type classification, and these uncertainties further affect aerosol extinction. Aerosol extinction coefficients are not analyzed due to values that are too low, with high uncertainties over the TP. In this study, four common seasons are defined, respectively, as March to May (spring), June to August (summer), September to November (autumn) and December to February the following year (winter).

The meridional circulations are examined using ERAInterim monthly mean reanalysis data, produced by the European Centre for Medium-Range Weather Forecasts (ECMWF). The spatial resolution of ERA-Interim reanalysis data is $0.75^{\circ} \times 0.75^{\circ}$, and the vertical layers at 32 differ- 

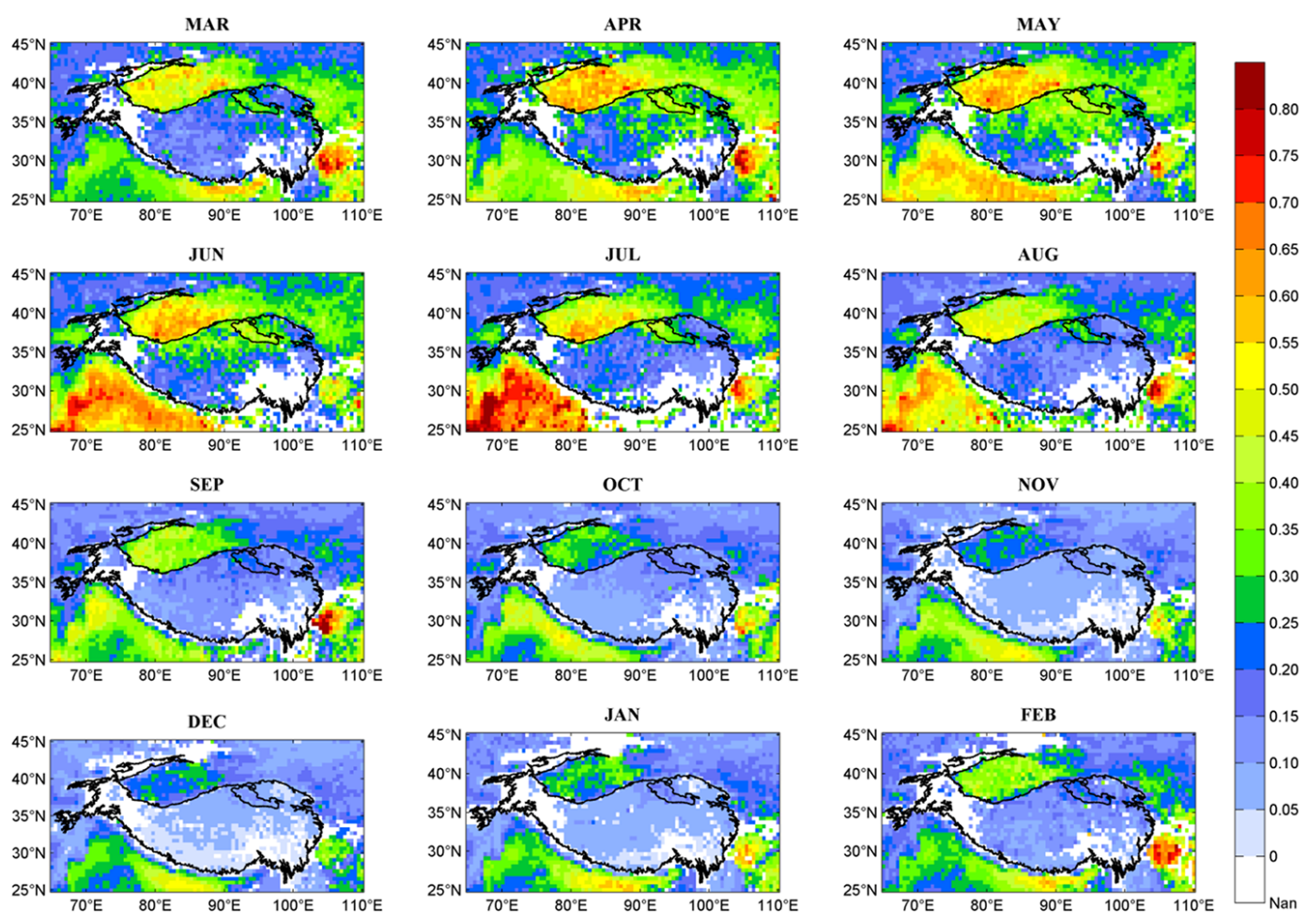

Figure 2. Monthly variations of AOD over the Tibetan Plateau. White shading indicates insufficient available data.

ent pressure levels are used (i.e., 1000, 975, 950, 925, 900, $875,850,825,800,775,750,700,650,600,550,500,450$, $400,350,300,250,225,200,175,150,125,100,70,50,30$, $20,10 \mathrm{hPa}$ ). Data are analyzed from March 2000 to February 2014.

\section{Results and analysis}

\subsection{Aerosol distribution characteristics}

Monthly variations of AOD over the Tibetan Plateau are shown in Fig. 2. Seasonal variations of AOD are significant. The monthly average of AOD for the $\sim 15$-year study period was less than $\sim 0.50$ over the whole TP in spring and summer, but less than 0.25 in autumn and winter. The highest AOD is shown over the Qaidam Basin on the TP in each month. Frequent dust storms mainly lead to the high AOD (Zhang et al., 2003; Wang et al., 2004). Human activities, including those such as fossil fuel combustion and industrial emissions over the Qaidam Basin, also contribute to the increasing aerosol concentrations to some extent (Streets et al., 2003; Zhang et al., 2009; Liu et al., 2015). The aerosol load increases gradually from March to May over the northern part of the TP, while it decreases from June to August. The areas with higher aerosol loads $(>0.25)$ expand gradually in April and reach their maximum extent in May, which indicates that AOD is highest in May. AOD is higher to the north of $33-34^{\circ} \mathrm{N}$ than to the south for the whole year. The east-west-trending mountains on the TP seem to act as a major natural barrier for the transport of atmospheric aerosols from north to south. The aerosol load increases slightly to the south of $30^{\circ} \mathrm{N}$ in summer. The aerosol load over the southern TP may be associated with the Indo-Gangetic Plain. A possible explanation of this phenomenon may be the peaks in anthropogenic emissions in the Indo-Gangetic Plain during summer coupled with suitable atmospheric circulation. Alpine valleys along the Himalayas (e.g., the Pulan Valley in the western Himalayas and the Yadong Valley in the middle Himalayas) may act as channels along which aerosols can be transported into the southern part of the TP during the monsoon season. In autumn and winter, AOD over the whole TP is mostly lower than 0.20, except in the Qaidam Basin. AOD even decreases below 0.10 over most regions of the TP from November to January. Unfortunately, AOD over the southeast TP cannot always be determined in each season due to thick cloud.

In summary, AOD is usually higher over the Qaidam Basin than over the other parts of the TP, throughout the year. Obvious seasonal variations of AOD are observed over the TP. Dust or anthropogenic emissions may pass through the northern edge of the TP, especially the Qaidam Basin, to intrude into the TP. 


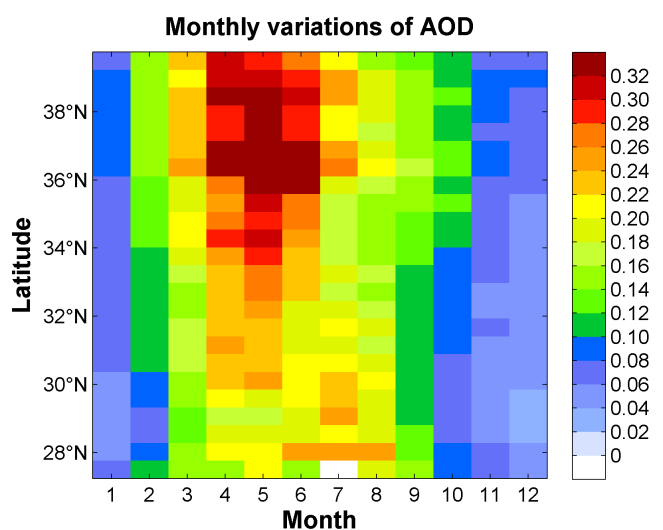

Figure 3. Zonal average of AOD over the Tibetan Plateau in each month. White shading indicates insufficient available data.

\subsection{Zonal variations in aerosol properties over the TP}

Although the aerosol load is quite low over the TP, the zonal distribution pattern can be seen clearly. Figure 3 shows the zonal monthly means of AOD for a period of over 15 years. Monthly variations in the northern TP are different from those in the southern TP. The aerosol load is relatively high over the northern TP during April to June, while it is high over the southern TP during June to August. Single monthly peak occurs over both the northern and southern TP. The monthly peak is observed in May and July, respectively. Moreover, the monthly zonal peak of AOD in the northern TP is about 1.5 times that in the southern part. Previous studies showed similar results based on surface observations (Gobbi et al., 2010; Xu et al., 2014). The zonal means over the whole TP are even below 0.10 during November to January.

Overall, AOD shows clear zonal distributions. Different monthly variation patterns of AOD are shown in the northern part and southern part of TP. The maximum aerosol concentration is observed during April to June to the region north of 33-34 $\mathrm{N}$, with maximum levels in May. Aerosols can be clearly transported to the south of about $30^{\circ} \mathrm{N}$ over the TP, with maximum levels in July.

\subsection{Vertical distributions of aerosols}

Dust, polluted dust, polluted continental aerosol and smoke retrieved by CALIPSO are the major aerosol types, possibly influencing the environment over the TP. The seasonal vertical distributions of these aerosol types are discussed in relation to the latitudinal transects. The regions from 80 to $100^{\circ} \mathrm{E}$ covering most of the TP are selected to represent aerosol three-dimensional distributions.

Figure 4 shows latitudinal transects of accumulated dust samples in each season. The features of aerosol threedimensional distributions can be concluded to seasonal variability and spatial differences. Dust generation and lofting is always active over the Tarim Basin and Hexi Corridor all year around, while dust occurs frequently over the northern Indian peninsula only in spring. Detected dust over the TP increases significantly in spring and summer, and dust occurs much less frequently in autumn and winter. This phenomenon possibly indicates that dust can be transported into the TP in spring and summer, while dust only occurs in Qaidam Basin in autumn and winter. Much less dust is detected on-plateau than off-plateau, which indicates that the TP acts as a large barrier for the transport of dust. Furthermore, dust occurrence decreases from the surface to the high altitude over the TP. Most Tibetan airborne dust is concentrated at a height of less than $7 \mathrm{~km}$ during spring and summer. Obvious differences of detected dust exist between the southern and northern TP in spring and summer. Dust occurs more frequently over the northern part of TP than the southern part. The demarcation between high dust occurrence over the northern TP and relatively low dust occurrence over the southern TP is clear along each longitudinal cross section. The demarcation runs east to west across the TP, which appears to be in accord with the distributions of monthly MISR AOD. After climbing the northern edge of the TP, dust reduces substantially. The extreme high mountains over the TP include the Kunlun and the Tanggula. When dust encounters these major mountains one by one, the detected dust aerosols passing through the mountains decrease gradually along the longitudinal zones from north to south in each season. The dust layer has the greatest depth over all the longitudinal zones in spring, followed by summer. In spring, dust layer extends from the surface to 11-12 km over the TP. Dust can be generated and lofted to a similar altitude over the Tarim Basin and Hexi Corridor in spring, whereas the dust layer exhibits a lesser thickness and extends to $6-8 \mathrm{~km}$ over the northern Indian peninsula. The detected aerosol layer even reaches up to upper troposphere and lower stratosphere over the TP and the regions north of the TP. Frequent dust activities and little precipitation may be favorable for dust intrusion in stratosphere. Stratospheretroposphere exchange is currently a widely studied topic, and aerosols intruding into the stratosphere will lead to a negative radiative forcing (Solomon et al., 2011). Previous studies have mainly focused on deep fast convective transport of polluted air from the atmospheric boundary layer into the upper troposphere and lower stratosphere during Asian summer monsoon season (Fu et al., 2006; Randel et al., 2010). The non-volcanic aerosol layer near the tropopause was detected vertically from 13 to $18 \mathrm{~km}$ based on CALIPSO observations during the Asian summer monsoon, and AOD here has increased 3 times since the late 1990s (Vernier et al., 2015). However, our results suggest the TP and the regions north of the TP may also act as alternative pathways for aerosols from the troposphere to the stratosphere during the spring period. The mechanisms of spring dust transport from the atmospheric boundary layer into the upper troposphere and lower stratosphere need further rigorous studies and discussions. The demarcation of dust occurrence between the northern and southern TP can be seen clearly from the surface to a 

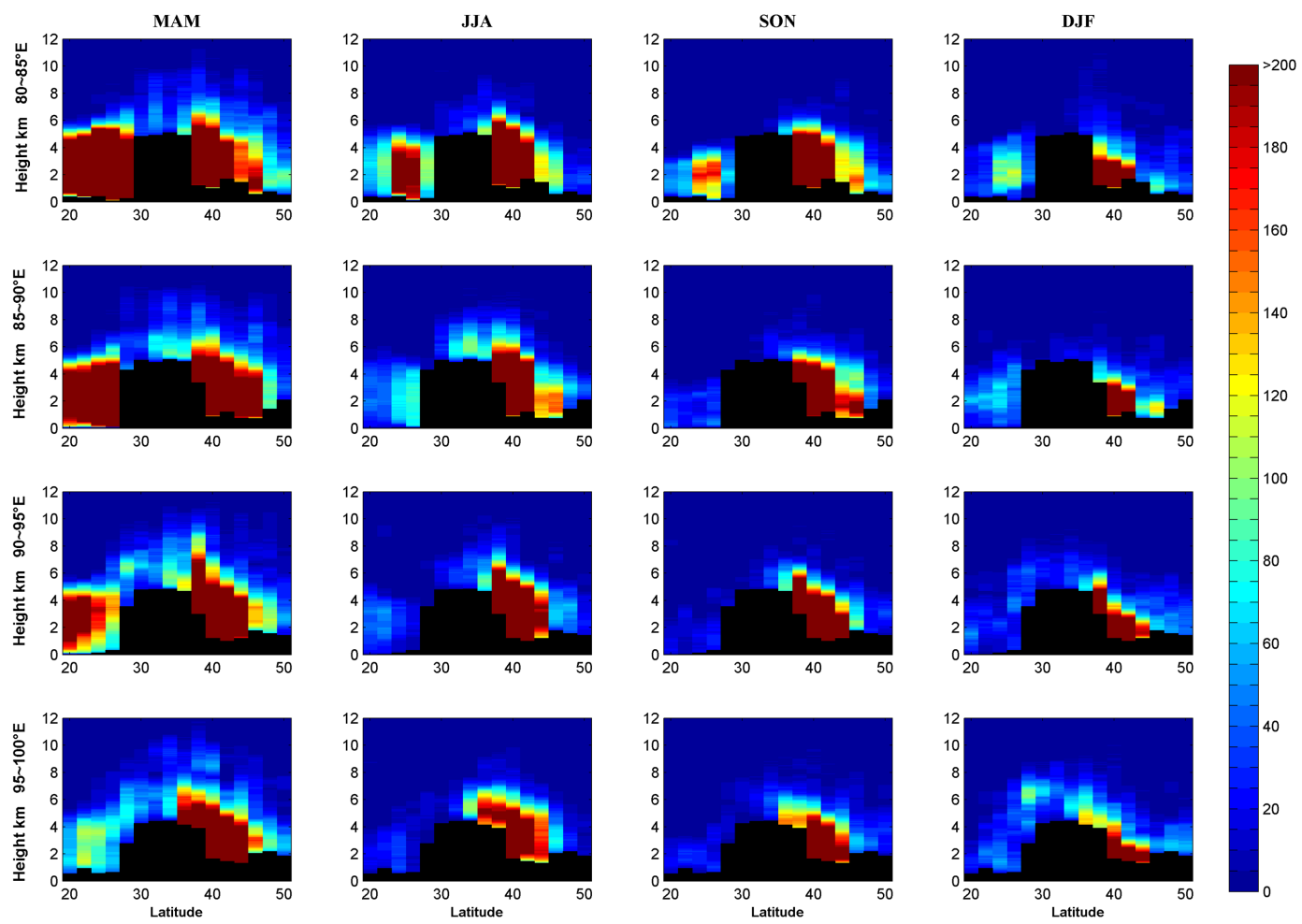

Figure 4. The detected accumulated dust samples for four seasons over the Tibetan Plateau and surrounding areas for four longitudinal transects $\left(80-85,85-90,90-95\right.$ and $95-100^{\circ}$ E). Black areas represent mountain profiles along the transects. MAM denotes March to May, JJA denotes June to August, SON denotes September to November and DJF denotes December to February the following year (the following season divisions are the same).

height of about 6-8 km during spring, while it becomes unapparent at high altitudes. The dust layer can only extend to the altitudes of $8-10 \mathrm{~km}$ over the TP during summer, and the demarcation appears to be obvious at an altitude of less than $7 \mathrm{~km}$. This phenomenon may indicate that dust seems to be transported more easily through the northern edge of TP than the southern edge during spring and summer. The dust layer is usually at altitudes of less than $8 \mathrm{~km}$ over the TP in autumn and winter. Due to low dust occurrence, the differences of detected dust between the northern and southern TP are not obvious in autumn and winter.

Figure 5 shows latitudinal transects of accumulated polluted dust samples in each season. Polluted dust also affects the environment of the TP. Nevertheless, the effect of polluted dust is not as significant as dust over the TP. High occurrence of polluted dust is observed over the northern Indian peninsula, except in summer, possibly due to large precipitation. The occurrence of polluted dust is higher than dust over the northern Indian peninsula except in spring. The polluted dust is confined to the lower $5 \mathrm{~km}$ of the atmosphere over the northern Indian peninsula in spring and summer, while polluted dust is concentrated at a height of less than $4 \mathrm{~km}$ in autumn and winter. The maximum height seems to be crucial to the long-range transport of polluted dust, considering that it is comparable to or lower than the altitude of the TP. Pol- luted dust cannot be transported onto the TP, when its maximum height is lower than the southern edge. Polluted dust also occurs to the north of the TP, but the effect is not obvious. Polluted dust decreases dramatically on-plateau relative to off-plateau regions. Only a small amount of polluted dust can be detected over the TP, and the number of polluted dust samples is a bit larger in spring and summer than in autumn and winter. The polluted dust layer also exhibits a relatively greater thickness over the TP in spring and summer. Differences of occurrence between the northern and southern part of TP also seem to be unapparent. Polluted dust rarely occur in autumn and winter, especially along the longitudinal cross section of 80-85, 85-90 and 90-95 ${ }^{\circ}$.

Figure 6 shows latitudinal transects of accumulated polluted continental samples in each season. Much less polluted continental samples are detected relative to dust or polluted dust over the study regions. This result does not mean that there is less urban air pollution in essence. Urban pollution mixed with dust is classified as polluted dust. Polluted continental aerosols seem to happen more frequently in autumn and winter over the northern Indian peninsula. Polluted continental aerosols hardly have any impact on the TP in each season.

Figure 7 shows latitudinal transects of accumulated smoke samples in each season. Smoke consisting of soot and OC 

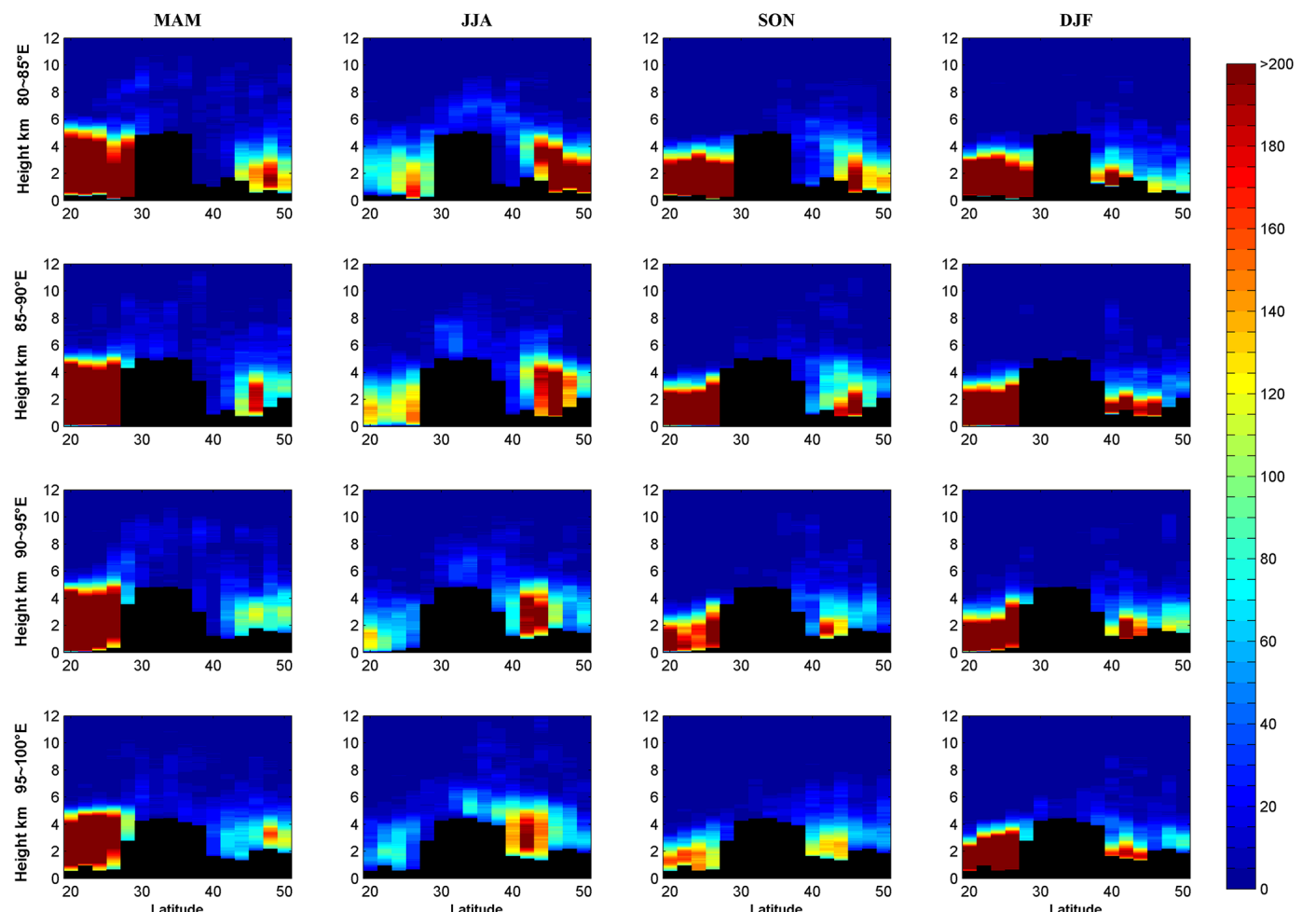

Figure 5. The detected accumulated polluted dust samples for four seasons over the Tibetan Plateau and surrounding areas for four longitudinal transects $\left(80-85,85-90,90-95\right.$ and $\left.95-100^{\circ} \mathrm{E}\right)$. Black areas represent mountain profiles along the transects.
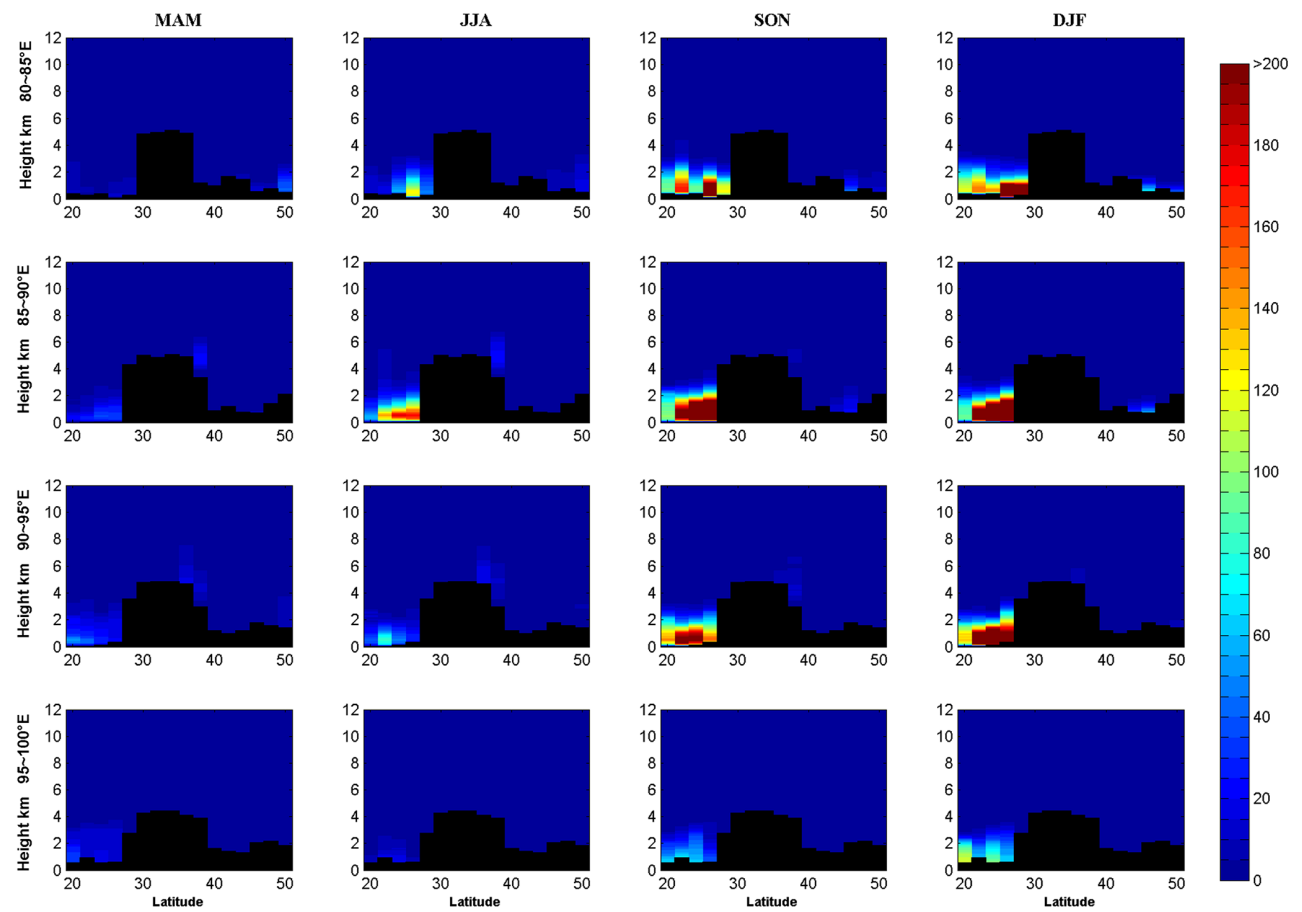

Figure 6. The detected accumulated polluted continental samples for four seasons over the Tibetan Plateau and surrounding areas for four longitudinal transects $\left(80-85,85-90,90-95\right.$ and $95-100^{\circ}$ E). Black areas represent mountain profiles along the transects. 

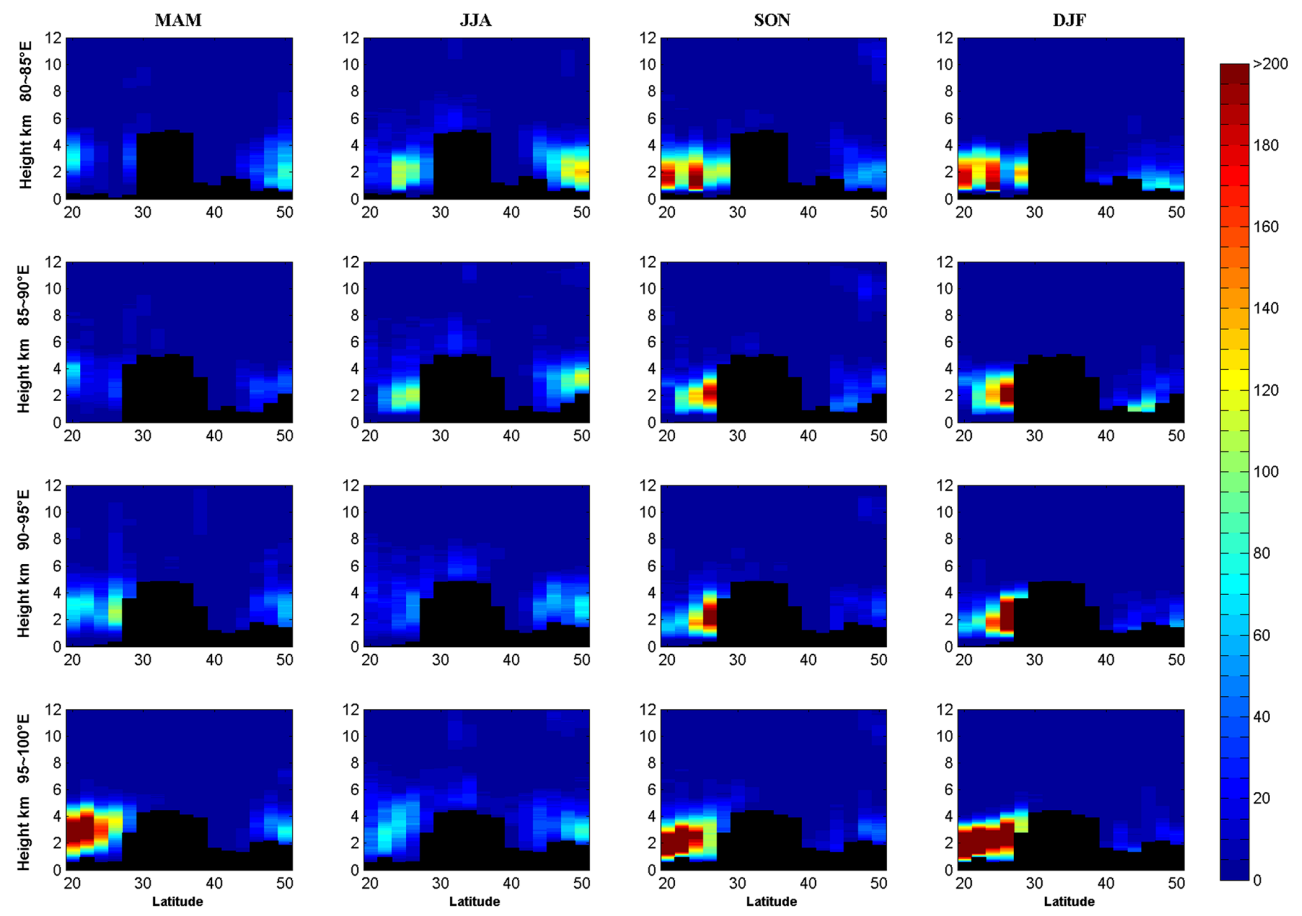

Figure 7. The detected accumulated smoke samples for four seasons over the Tibetan Plateau and surrounding areas for four longitudinal transects $\left(80-85,85-90,90-95\right.$ and $\left.95-100^{\circ} \mathrm{E}\right)$. Black areas represent mountain profiles along the transects.

can be transported to the main body of the TP. More smoke samples are detected over the Indo-Gangetic Plain rather than the areas north of the TP. The altitude of smoke aerosol layer is higher in summer than other seasons over the IndoGangetic Basin. Although the heavy summer rains remove a large amount of soluble gases and aerosols, less-soluble species can be lifted to the upper troposphere in deep convective clouds and then be transported away from the IndoGangetic Plain by strong upper tropospheric winds. In spring, few smoke samples are detected above the TP, and do not show a continuous vertical distribution. This indicates that smoke released during big fires can be occasionally uplifted above the atmospheric boundary layer and further transported to the TP. Detected smoke samples increase lightly over the TP during summer, and they are also not continuous in column. Although smoke does not occur during summer as frequently as autumn or winter over the northern Indian peninsula, strong southerly winds blow towards the TP only during summer. Smoke can even suspend at an altitude of $12 \mathrm{~km}$ over the TP in summer. Detected smoke samples are a bit higher in the central TP in summer, which may be due to local emission. Detected smoke samples decrease again in autumn, and smoke usually occurs less than $7 \mathrm{~km}$ over the TP. Smoke occurrence is a bit higher in the southern part of the TP than the northern part in summer and autumn. Smoke appears to be more likely transported from the northern Indian peninsula to the TP in summer and autumn, because higher occurrence of smoke is shown in the adjacent regions of the southern edge. No smoke samples are detected over the TP in winter.

In summary, pure dust is found to be the main aerosol type above the TP, and dust mixed with pollution or smoke occasionally occurs. Smoke only has a little effect on the TP in summer, while urban pollution does not contaminate the environment of the TP individually. Much fewer aerosols are detected on-plateau than off-plateau, which indicates that the $\mathrm{TP}$ acts as a natural barrier. Dust and polluted dust exhibit more thickness in spring and summer above the TP. The bulk of dust is concentrated at a height of less than $7 \mathrm{~km}$ during spring and summer. Different dust occurrences between the northern and southern TP can be found clearly in spring and summer. No significant differences are found in the occurrences of polluted dust, smoke or polluted continental aerosols over the northern and southern TP. Smoke aerosols may be more likely to come from the northern Indian peninsula in summer.

\subsection{Possible factors contributing to the aerosol distribution pattern}

The TP has quite pristine atmospheric conditions; that is to say, few aerosols come from local contributions. Zhang et al. (2015) showed that local emissions contributed only a small percentage of $\mathrm{BC}$ in the Himalayas and Tibetan Plateau. There are no obvious sources of biomass burning on the TP (Mouillot and Field, 2005). As the most prominent aerosol type on the TP, airborne dust on the TP mostly comes 

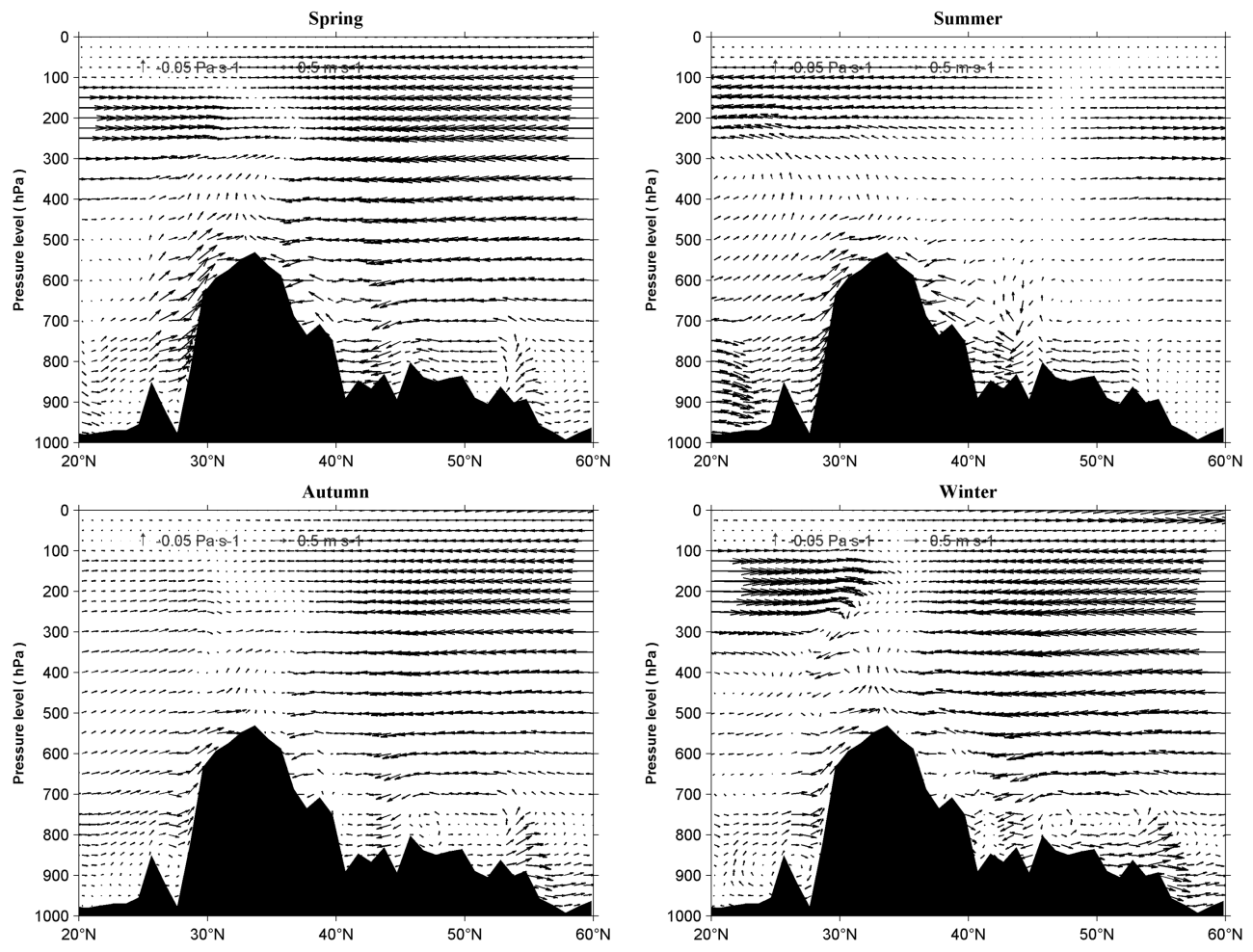

Figure 8. The meridional circulation at $95^{\circ} \mathrm{E}$ in the four seasons. The black shading shows the altitudes of the Tibetan Plateau at $95^{\circ} \mathrm{E}$.

from the surrounding regions. A negative or significant negative relationship between AOD and wind speed was found over most regions of the TP based on previous results ( $\mathrm{Ge}$ et al., 2014). Therefore, long-range transport of aerosols primarily impacts the atmospheric environment over the TP, and this study is not focused on the contribution of inner sources on the TP. The aerosol load has significant seasonal variations. Interestingly, the pattern of seasonal variations over the northern TP is different to that of the southern part; this could be due to many factors, including the emission sources, highaltitude terrain and atmospheric circulation.

Much higher aerosol loads are observed over the surrounding regions of the TP. AOD peaks during spring and summer over Tarim Basin. Strong anticyclonic wind anomaly at $500 \mathrm{hPa}$ and enhanced easterly wind at $850 \mathrm{hPa}$ over the Tarim Basin during spring and summer are good for dust entrainment, vertical lofting, and horizontal transport (Ge et al., 2014). The Indo-Gangetic Basin, encompassing most of northern India peninsula, extends from Pakistan in the west to Bangladesh in the east. The Indo-Gangetic Basin is one of the most heavily populated regions of the world. There are a large quantity of emissions of biomass burning and fossil fuel over south Asia, adjacent to the TP (Ramanathan et al., 2005). AOD over the Indo-Gangetic Basin can reach extremely high values throughout the year, peaking during spring and summer due to enhanced emission of natural aerosols (Dey and Di Girolamo, 2010). Furthermore, aerosol layers exist above the TP over the northern Indian peninsula and Tarim Basin during spring and summer. Dust and polluted dust layers exhibit a relatively greater thickness over the regions north of the TP than the regions south of the TP during spring and summer. The aerosol concentrations and the heights of aerosol layers over the surrounding regions have a great influence on the transport of aerosols.

The high terrain acts as a natural barrier for the transport of atmospheric aerosols from the surrounding polluted regions to the main body of the TP due to its topographic characteristics. Therefore, AOD over the TP is much lower than that of surrounding regions, such as the Taklamakan Desert and the Indo-Gangetic Plain. The aerosol distributions are impacted by the mountain ranges on the TP. The high aerosol load occurring over the northern part seems to be associated with lower altitudes, and a relatively low aerosol load along the southern edge seems to be associated with the higher altitudes. The aerosol layer firstly needs to be present higher than the TP elevation, which is a requirement for aerosol transport to the TP. The southern edge is much higher than the northern edge of the TP. The transport of aerosols from north of the TP seems easier than from south of the TP. Aerosols may only pass through alpine valleys along the Himalayas to intrude into the TP, while a broader northeastern edge - especially the Qaidam Basin - seems to provide transmission channels. When aerosols pass across the northern edge, the major natural obstacles they encounter are several 

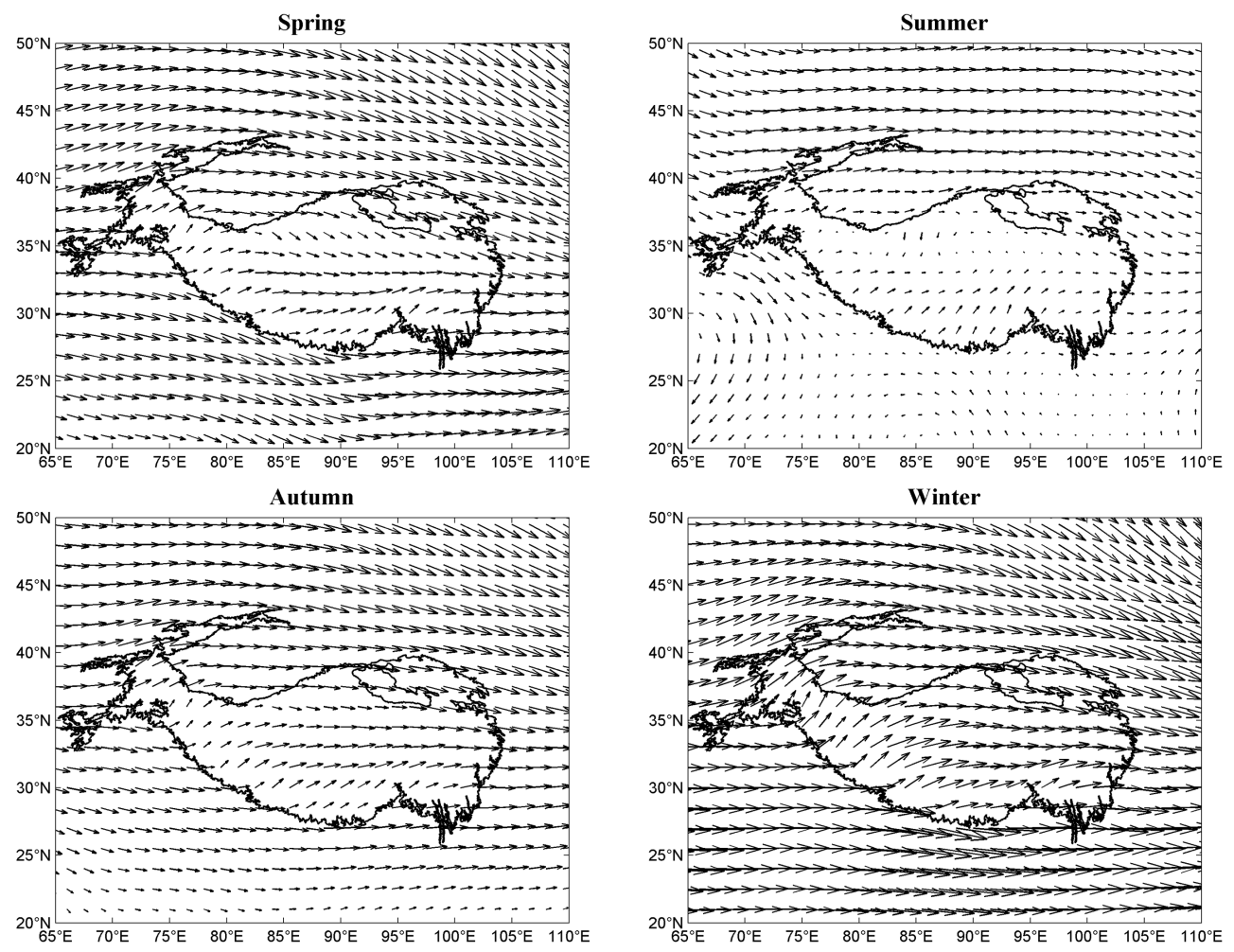

Figure 9. Spatial distribution of wind at $500 \mathrm{hPa}$ over the Tibetan Plateau in the four seasons.

mountains. The Kunlun and the Tanggula mountains act as barriers which block aerosols. It is then difficult for aerosols to spread further southward. The Gangdise and the Nyainqêntanglha mountains are located around $30-31^{\circ} \mathrm{N}$ on the southern TP. These mountains possibly act as a natural barrier for aerosols passing across the southern edge, and curb the spread of pollution further northward to the main body of the TP. The demarcation extending to $6-8 \mathrm{~km}$ seems to exist only in dust aerosols, while it is not apparent in other types of aerosols due to their small amounts. The high-altitude terrain located around $33-35^{\circ} \mathrm{N}$ in the middle of the plateau appears to be geographically identical to this natural demarcation. Not only does the whole TP block the atmospheric aerosols, but also the extreme high mountains on the TP cause an obstruction to the transport of aerosols.

Atmospheric circulation also greatly impacts the seasonal aerosol variations. Figure 8 shows the annual average vertical wind fields, and Fig. 9 shows the wind vector field at $500 \mathrm{hPa}$. A longitude of $95^{\circ} \mathrm{E}$, corresponding to the Qaidam Basin, is chosen to analyze the vertical atmospheric circulations. During the spring period, the northern air flows and southern air flows intersect at about $31-32^{\circ} \mathrm{N}$ over the TP. Aerosols above the TP are mostly from the northern side of the TP in spring, and aerosols originating from the IndoGangetic Basin may only affect the area south of $31-32^{\circ} \mathrm{N}$ on the TP. Northwesterly and westerly winds at $500 \mathrm{hPa}$ prevail over the Indo-Gangetic Plain during spring. Although high aerosol load occurs and aerosol layer exists at $5 \mathrm{~km}$ during spring, this atmospheric circulation does not benefit to the transport of air pollutants from the northern India to the TP. Kuhlmann and Quaas (2010) reported that around $40 \%$ of elevated desert dust or polluted dust from Iran and Pakistan can be advected towards the southern slope of TP. During summer, the airflows originating from both the northern and southern sides of the TP carry aerosols to the main body of the TP. The Indo-Gangetic Basin is dominated by a cyclonic circulation system at $500 \mathrm{hPa}$. In addition, vertical circulation indicates strong updrafts below $200 \mathrm{hPa}$ to the south of the TP. Updrafts are also shown on the whole TP. With the summer monsoon developing, the southwesterly winds at $500 \mathrm{hPa}$ reach the northward maximum extent over the TP. Furthermore, the northern atmospheric circulation system and south Asian monsoonal system meet around $34-35^{\circ} \mathrm{N}$ in the middle of the TP. The atmospheric circulation promotes the transport of aerosols from the Tarim Basin, Qaidam Basin and Indo-Gangetic Basin to the main body of the TP. It might be reasonably deduced that atmospheric circulation possibly leads to the formation of different seasonal variation patterns of aerosols between the northern and southern TP. Dust particles coated by pollution acids can provide the predominant source of cloud condensation nuclei (Ma et al., 2010). Urban emissions consisting of hygroscopic compounds could be deposited by heavy precipitation and reduce substantially over the northern Indian peninsula. 
Some less-soluble species can be lifted to the upper troposphere in deep convective clouds and then be transported to the TP by strong upper tropospheric winds. The strong southwesterly winds can provide the dynamical conditions for the transport of aerosols during monsoon season, which leads to the highest aerosol load occurring in July over the southern TP. The aerosol particles continue to reduce drastically after passing through the Himalayas Mountains due to the physical blocking. Consequently, the aerosol loading and occurrences are still higher in the northern TP than the southern TP during summer. Seasonal variations of atmospheric circulations lead to the relatively higher aerosol loads in spring and summer on the TP. During autumn, southwesterly winds mainly prevail south of $31-32^{\circ} \mathrm{N}$ at $500 \mathrm{hPa}$ on the TP with the retreat of monsoon. During the winter period, wind fields are similar to autumn but with higher wind velocities. Westerly winds at $500 \mathrm{hPa}$ gradually prevail over the Indo-Gangetic Basin from autumn to winter. Moreover, our results reveal that the aerosol layer usually exists at an altitude of less than $4 \mathrm{~km}$ over the Indo-Gangetic Basin during autumn and winter. Aerosols originating from Indo-Gangetic Basin cannot be lifted to a height higher than the elevation of the southern edge during autumn and winter. Conversely, some elevated dust aerosol layers higher than the northern edge of the TP are observed north of the TP during autumn and winter. It is difficult for aerosols transported from the Indo-Gangetic Basin to the TP during autumn and winter seasons. Elevated dust aerosols from the north of the TP can be possibly transported to the TP coupled with northward winds.

\section{Concluding remarks}

This study identifies the patterns of aerosol variations over the TP using the 15-year MISR data. Furthermore, the vertical distributions of dust, polluted dust, polluted continental aerosols and smoke retrieved by 8-year CALIPSO data are also investigated over the TP. The possible reasons for the temporal variations and spatial distributions of aerosols are discussed.

The aerosol load exhibits obvious seasonal variations over the investigated regions, with higher AOD observed during spring and summer. Two different kinds of seasonal patterns of AOD are observed over the TP. The maximum monthly AOD over the northern TP occurs in May, while AOD over the southern TP peaks in July. AOD shows much higher values over Qaidam Basin than other parts of the TP throughout the year. Monthly AOD usually shows higher values over the northern TP than the southern TP. Dust is found to be the major aerosol type above the TP, while polluted dust and smoke aerosols slightly affect the atmospheric environment on the TP. Therefore, the seasonal variation and spatial pattern of aerosol load are largely associated with dust occurrence. Both the occurrence and the thickness of airborne dust also reach maximums over the TP in spring. The dust layer over the TP can reach up to the upper troposphere and lower stratosphere in spring (altitudes of $\sim 11-12 \mathrm{~km}$ ), while the altitude of dust layer is much lower in other seasons. Higher dust occurrence in the northern TP and lower dust occurrence in the southern TP are observed during spring and summer. This dividing line is located around $33-35^{\circ} \mathrm{N}$ in the middle of the plateau. In addition, this demarcation extends from the surface to an altitude of $6-8 \mathrm{~km}$. However, this demarcation is not observed in the distributions of other aerosol types due to their low occurrences.

The seasonal variations and distribution characteristics of the aerosol load on the TP are possibly affected by many factors, including emission sources, the height of aerosol layer, atmospheric circulation and the topography of the TP. High concentrations of aerosols exist during spring and summer over the surrounding regions including the Indo-Gangetic Basin and the Tarim Basin. Furthermore, aerosol layers exist above the TP elevation during these two seasons. These conditions are favorable for aerosol transport from the surrounding regions to the TP. Different seasonal variations over the northern and southern TP are closely associated with atmospheric circulation system. Atmospheric circulations also greatly control the potential maximum limit of aerosol transport. However, the actual distribution patterns of aerosol are not completely consistent with the maximum extent of airflows. The mountains on the TP may effectively block the transport of aerosols. It is the possible reason that a dividing line of different dust occurrences between the southern and northern TP exists in the middle of the TP during spring and summer.

Acknowledgements. This research was funded by the Chinese Academy of Sciences (XDB03030201), the National Natural Science Foundation of China (91337212, 41275010, 41375009), the CMA Special Fund for Scientific Research in the Public Interest (GYHY201406001) and EU-FP7 projects "CORE-CLIMAX" (313085). This study was also funded by the CAS "Hundred Talent" program (Weiqiang Ma). We would like to thank the editor and two anonymous referees for their very valuable comments greatly improving the paper. The MISR data were obtained from the NASA Langley Research Center Atmospheric Science Data Center. The CALIPSO data were obtained from the NASA Langley Research Center Atmospheric Science Data Center. The ERA-Interim data were produced by ECMWF. The first author would like to acknowledge Changgui Lin, You He and all the other group members for their help in preparing the paper.

Edited by: H. Su

\section{References}

Abdou, W. A., Diner, D. J., Martonchik, J. V., Bruegge, C. J., Kahn, R. A., Gaitley, B. J., Crean, K. A., Remer, L. A., and Holben, B.: Comparison of coincident Multiangle Imaging Spectroradiometer and Moderate Resolution Imaging Spectroradiometer aerosol 
optical depths over land and ocean scenes containing Aerosol Robotic Network sites, J. Geophys. Res.-Atmos., 110, D10S07, doi:10.1029/2004JD004693, 2005.

Bucci, S., Cagnazzo, C., Cairo, F., Di Liberto, L., and Fierli, F.: Aerosol variability and atmospheric transport in the Himalayan region from CALIOP 2007-2010 observations, Atmos. Chem. Phys., 14, 4369-4381, doi:10.5194/acp-14-4369-2014, 2014.

Burton, S. P., Ferrare, R. A., Vaughan, M. A., Omar, A. H., Rogers, R. R., Hostetler, C. A., and Hair, J. W.: Aerosol classification from airborne HSRL and comparisons with the CALIPSO vertical feature mask, Atmos. Meas. Tech., 6, 13971412, doi:10.5194/amt-6-1397-2013, 2013.

Cao, J., Tie, X., Xu, B., Zhao, Z., Zhu, C., Li, G., and Liu, S.: Measuring and modeling black carbon (BC) contamination in the SE Tibetan Plateau, J. Atmos. Chem., 67, 45-60, doi:10.1007/s10874-011-9202-5, 2010.

Cong, Z., Kang, S., Kawamura, K., Liu, B., Wan, X., Wang, Z., Gao, S., and Fu, P.: Carbonaceous aerosols on the south edge of the Tibetan Plateau: concentrations, seasonality and sources, Atmos. Chem. Phys., 15, 1573-1584, doi:10.5194/acp-15-15732015, 2015.

Dey, S. and Di Girolamo, L.: A climatology of aerosol optical and microphysical properties over the Indian subcontinent from 9 years (2000-2008) of Multiangle Imaging Spectroradiometer (MISR) data, J. Geophys. Res., 115, D15204, doi:10.1029/2009jd013395, 2010.

Di Girolamo, L. and Wilson, M. J.: A first look at banddifferenced angular signatures for cloud detection from MISR, IEEE T. Geoscience and Remote Sensing, 41, 1730-1734, doi:10.1109/TGRS.2003.815659, 2003.

Fu, R., Hu, Y., Wright, J. S., Jiang, J. H., Dickinson, R. E., Chen, M., Filipiak, M., Read, W. G., Waters, J. W., and Wu, D. L.: Short circuit of water vapor and polluted air to the global stratosphere by convective transport over the Tibetan Plateau, P. Natl. Acad. Sci., 103, 5664-5669, doi:10.1073/pnas.0601584103, 2006.

Gautam, R., Hsu, N. C., Tsay, S. C., Lau, K. M., Holben, B., Bell, S., Smirnov, A., Li, C., Hansell, R., Ji, Q., Payra, S., Aryal, D., Kayastha, R., and Kim, K. M.: Accumulation of aerosols over the Indo-Gangetic plains and southern slopes of the Himalayas: distribution, properties and radiative effects during the 2009 pre-monsoon season, Atmos. Chem. Phys., 11, 1284112863, doi:10.5194/acp-11-12841-2011, 2011.

Ge, J. M., Huang, J. P., Xu, C. P., Qi, Y. L., and Liu, H. Y.: Characteristics of Taklimakan dust emission and distribution: A satellite and reanalysis field perspective, J. Geophys. Res.-Atmos., 119, 11772-11783, doi:10.1002/2014JD022280, 2014.

Gobbi, G. P., Angelini, F., Bonasoni, P., Verza, G. P., Marinoni, A., and Barnaba, F.: Sunphotometry of the 2006-2007 aerosol optical/radiative properties at the Himalayan Nepal Climate Observatory-Pyramid (5079 m a.s.1.), Atmos. Chem. Phys., 10, 11209-11221, doi:10.5194/acp-10-11209-2010, 2010.

Huang, J., Minnis, P., Yi, Y., Tang, Q., Wang, X., Hu, Y., Liu, Z., Ayers, K., Trepte, C., and Winker, D.: Summer dust aerosols detected from CALIPSO over the Tibetan Plateau, Geophys. Res. Lett., 34, L18805, doi:10.1029/2007g1029938, 2007.

Kahn, R. A.: Multiangle Imaging Spectroradiometer (MISR) global aerosol optical depth validation based on 2 years of coincident Aerosol Robotic Network (AERONET) observations, J. Geophys. Res., 110, D10S04, doi:10.1029/2004jd004706, 2005.
Kahn, R. A., Gaitley, B. J., Garay, M. J., Diner, D. J., Eck, T. F., Smirnov, A., and Holben, B. N.: Multiangle Imaging SpectroRadiometer global aerosol product assessment by comparison with the Aerosol Robotic Network, J. Geophys. Res.-Atmos., 115, D23209, doi:10.1029/2010jd014601, 2010.

Kaufman, Y. J., Tanre, D., and Boucher, O.: A satellite view of aerosols in the climate system, Nature, 419, 215-223, doi:10.1038/nature01091, 2002.

King, M. D., Kaufman, Y. J., Tanré, D., and Nakajima, T.: Remote Sensing of Tropospheric Aerosols from Space: Past, Present, and Future, B. Am. Meteorol. Soc., 80, 2229-2259 1999.

Kuhlmann, J. and Quaas, J.: How can aerosols affect the Asian summer monsoon? Assessment during three consecutive premonsoon seasons from CALIPSO satellite data, Atmos. Chem. Phys., 10, 4673-4688, doi:10.5194/acp-10-4673-2010, 2010.

Li, Z., Li, C., Chen, H., Tsay, S. C., Holben, B., Huang, J., Li, B., Maring, H., Qian, Y., Shi, G., Xia, X., Yin, Y., Zheng, Y., and Zhuang, G.: East Asian Studies of Tropospheric Aerosols and their Impact on Regional Climate (EASTAIRC): An overview, J. Geophys. Res.-Atmos., 116, D00K34, doi:10.1029/2010jd015257, 2011.

Lin, C., Yang, K., Qin, J., and Fu, R.: Observed Coherent Trends of Surface and Upper-Air Wind Speed over China since 1960, J. Climate, 26, 2891-2903, doi:10.1175/JCLI-D-12-00093.1, 2012.

Liu, D., Wang, Z., Liu, Z., Winker, D., and Trepte, C.: A height resolved global view of dust aerosols from the first year CALIPSO lidar measurements, J. Geophys. Res.-Atmos., 113, D16214, doi:10.1029/2007JD009776, 2008.

Liu, Z., Liu, D., Huang, J., Vaughan, M., Uno, I., Sugimoto, N., Kittaka, C., Trepte, C., Wang, Z., Hostetler, C., and Winker, D.: Airborne dust distributions over the Tibetan Plateau and surrounding areas derived from the first year of CALIPSO lidar observations, Atmos. Chem. Phys., 8, 5045-5060, doi:10.5194/acp-85045-2008, 2008.

Liu, Z., Guan, D., Wei, W., Davis, S. J., Ciais, P., Bai, J., Peng, S., Zhang, Q., Hubacek, K., Marland, G., Andres, R. J., CrawfordBrown, D., Lin, J., Zhao, H., Hong, C., Boden, T. A., Feng, K., Peters, G. P., Xi, F., Liu, J., Li, Y., Zhao, Y., Zeng, N., and He, K.: Reduced carbon emission estimates from fossil fuel combustion and cement production in China, Nature, 524, 335-338, doi:10.1038/nature14677, 2015.

Ma, J., Chen, Y., Wang, W., Yan, P., Liu, H., Yang, S., Hu, Z., and Lelieveld, J.: Strong air pollution causes widespread hazeclouds over China, J. Geophys. Res.-Atmos/, 115, D18204, doi:10.1029/2009JD013065, 2010.

Ma, Y., Zhong, L., Wang, B., Ma, W., Chen, X., and Li, M.: Determination of land surface heat fluxes over heterogeneous landscape of the Tibetan Plateau by using the MODIS and in situ data, Atmos. Chem. Phys., 11, 10461-10469, doi:10.5194/acp11-10461-2011, 2011.

Ma, Y., Han, C., Zhong, L., Wang, B., Zhu, Z., Wang, Y., Zhang, L., Meng, C., Xu, C., and Amatya, P.: Using MODIS and AVHRR data to determine regional surface heating field and heat flux distributions over the heterogeneous landscape of the Tibetan Plateau, Theor. Appl. Climatol., 117, 643-652, doi:10.1007/s00704-013-1035-5, 2014a.

Ma, Y., Zhu, Z., Zhong, L., Wang, B., Han, C., Wang, Z., Wang, Y., Lu, L., Amatya, P. M., Ma, W., and Hu, Z.: Combining MODIS, AVHRR and in situ data for evapotranspiration estimation over 
heterogeneous landscape of the Tibetan Plateau, Atmos. Chem. Phys., 14, 1507-1515, doi:10.5194/acp-14-1507-2014, 2014b.

Martonchik, J. V., Diner, D. J., Kahn, R., Gaitley, B., and Holben, B. N.: Comparison of MISR and AERONET aerosol optical depths over desert sites, Geophys. Res. Lett., 31, L16102, doi:10.1029/2004g1019807, 2004.

Mielonen, T., Arola, A., Komppula, M., Kukkonen, J., Koskinen, J., de Leeuw, G., and Lehtinen, K. E. J.: Comparison of CALIOP level 2 aerosol subtypes to aerosol types derived from AERONET inversion data, Geophys. Res. Lett., 36, L18804, doi:10.1029/2009GL039609, 2009.

Moroney, C., Davies, R., and Muller, J. P.: Operational retrieval of cloud-top heights using MISR data, IEEE T. Geoscience and Remote Sensing, 40, 1532-1540, doi:10.1109/TGRS.2002.801150, 2002.

Mouillot, F. and Field, C. B.: Fire history and the global carbon budget: a $1^{\circ} \times 1^{\circ}$ fire history reconstruction for the 20th century, Glob. Change Biol., 11, 398-420, doi:10.1111/j.13652486.2005.00920.x, 2005.

Omar, A. H., Winker, D. M., Vaughan, M. A., Hu, Y., Trepte, C. R., Ferrare, R. A., Lee, K.-P., Hostetler, C. A., Kittaka, C., Rogers, R. R., Kuehn, R. E., and Liu, Z.: The CALIPSO Automated Aerosol Classification and Lidar Ratio Selection Algorithm, J. Atmos. Ocean. Tech., 26, 1994-2014, doi:10.1175/2009JTECHA1231.1, 2009.

Ramanathan, V., Crutzen, P. J., Kiehl, J. T., and Rosenfeld, D.: Aerosols, climate, and the hydrological cycle, Science, 294, 2119-2124, doi:10.1126/science.1064034, 2001.

Ramanathan, V., Chung, C., Kim, D., Bettge, T., Buja, L., Kiehl, J. T., Washington, W. M., Fu, Q., Sikka, D. R., and Wild, M.: Atmospheric brown clouds: impacts on South Asian climate and hydrological cycle, P. Natl. Acad. Sci. USA, 102, 5326-5333, doi:10.1073/pnas.0500656102, 2005.

Randel, W. J., Park, M., Emmons, L., Kinnison, D., Bernath, P., Walker, K. A., Boone, C., and Pumphrey, H.: Asian Monsoon Transport of Pollution to the Stratosphere, Science, 328, 611613, doi:10.1126/science.1182274, 2010.

Sheng, J., Wang, X., Gong, P., Joswiak, D. R., Tian, L., Yao, T., and Jones, K. C.: Monsoon-Driven Transport of Organochlorine Pesticides and Polychlorinated Biphenyls to the Tibetan Plateau: Three Year Atmospheric Monitoring Study, Environ. Sci. Technol., 47, 3199-3208, doi:10.1021/es305201s, 2013.

Shi, Y., Zhang, J., Reid, J. S., Liu, B., and Hyer, E. J.: Critical evaluation of cloud contamination in the MISR aerosol products using MODIS cloud mask products, Atmos. Meas. Tech., 7, 17911801, doi:10.5194/amt-7-1791-2014, 2014.

Solomon, S., Daniel, J. S., Neely III, R. R., Vernier, J. P., Dutton, E. G., and Thomason, L. W.: The Persistently Variable "Background" Stratospheric Aerosol Layer and Global Climate Change, Science, 333, 866-870, doi:10.1126/science.1206027, 2011.

Streets, D. G., Bond, T. C., Carmichael, G. R., Fernandes, S. D., Fu, Q., He, D., Klimont, Z., Nelson, S. M., Tsai, N. Y., Wang, M. Q., Woo, J. H., and Yarber, K. F.: An inventory of gaseous and primary aerosol emissions in Asia in the year 2000, J. Geophys. Res.-Atmos., 108, 8809, doi:10.1029/2002JD003093, 2003.

Tian, L., Yao, T., MacClune, K., White, J. W. C., Schilla, A., Vaughn, B., Vachon, R., and Ichiyanagi, K.: Stable isotopic varia- tions in west China: A consideration of moisture sources, J. Geophys. Res., 112, D10112, doi:10.1029/2006jd007718, 2007.

Vernier, J. P., Thomason, L. W., and Kar, J.: CALIPSO detection of an Asian tropopause aerosol layer, Geophys. Res. Lett., 38, L07804, doi:10.1029/2010g1046614, 2011.

Vernier, J. P., Fairlie, T. D., Natarajan, M., Wienhold, F. G., Bian, J., Martinsson, B. G., Crumeyrolle, S., Thomason, L. W., and Bedka, K. M.: Increase in upper tropospheric and lower stratospheric aerosol levels and its potential connection with Asian pollution, J. Geophys. Res.-Atmos., 120, 1608-1619, doi:10.1002/2014JD022372, 2015.

Wang, X., Dong, Z., Zhang, J., and Liu, L.: Modern dust storms in China: an overview, J. Arid Environ., 58, 559-574, doi:10.1016/j.jaridenv.2003.11.009, 2004.

Winker, D. M., Hunt, W. H., and McGill, M. J.: Initial performance assessment of CALIOP, Geophys. Res. Lett., 34, L19803, doi:10.1029/2007g1030135, 2007.

Winker, D. M., Pelon, J., Coakley, J. A., Ackerman, S. A., Charlson, R. J., Colarco, P. R., Flamant, P., Fu, Q., Hoff, R. M., Kittaka, C., Kubar, T. L., Le Treut, H., McCormick, M. P., Mégie, G., Poole, L., Powell, K., Trepte, C., Vaughan, M. A., and Wielicki, B. A.: The CALIPSO Mission: A Global 3D View of Aerosols and Clouds, B. Am. Meteorol. Soc., 91, 1211-1229, doi:10.1175/2010BAMS3009.1, 2010.

Winker, D. M., Tackett, J. L., Getzewich, B. J., Liu, Z., Vaughan, M. A., and Rogers, R. R.: The global 3-D distribution of tropospheric aerosols as characterized by CALIOP, Atmos. Chem. Phys., 13, 3345-3361, doi:10.5194/acp-13-3345-2013, 2013.

Witek, M. L., Garay, M. J., Diner, D. J., and Smirnov, A.: Aerosol optical depths over oceans: A view from MISR retrievals and collocated MAN and AERONET in situ observations, J. Geophys. Res.-Atmos., 118, 2013JD020393, doi:10.1002/2013JD020393, 2013.

Wu, G., Liu, Y., Zhang, Q., Duan, A., Wang, T., Wan, R., Liu, X., Li, W., Wang, Z., and Liang, X.: The Influence of Mechanical and Thermal Forcing by the Tibetan Plateau on Asian Climate, J. Hydrometeorol., 8, 770-789, doi:10.1175/JHM609.1, 2007.

Wu, G., Liu, Y., He, B., Bao, Q., Duan, A., and Jin, F.-F.: Thermal Controls on the Asian Summer Monsoon, Scientific Reports, 2, 404, doi:10.1038/srep00404, 2012.

Wu, G., Zhang, C., Xu, B., Mao, R., Joswiak, D., Wang, N., and Yao, T.: Atmospheric dust from a shallow ice core from Tanggula: implications for drought in the central Tibetan Plateau over the past 155 years, Quaternary Sci. Rev., 59, 57-66, doi:10.1016/j.quascirev.2012.10.003, 2013.

Xia, X., Wang, P., Wang, Y., Li, Z., Xin, J., Liu, J., and Chen, H.: Aerosol optical depth over the Tibetan Plateau and its relation to aerosols over the Taklimakan Desert, Geophys. Res. Lett., 35, L16804, doi:10.1029/2008g1034981, 2008.

Xia, X. G., Zong, X. M., Cong, Z. Y., Chen, H. B., Kang, S. C., and Wang, P. C.: Baseline continental aerosol over the central Tibetan plateau and a case study of aerosol transport from South Asia, Atmos. Environ., 45, 7370-7378, 2011.

Xu, B., Cao, J., Hansen, J., Yao, T., Joswia, D. R., Wang, N., Wu, G., Wang, M., Zhao, H., and Yang, W.: Black soot and the survival of Tibetan glaciers, P. Natl. Acad. Sci., 106, 22114-22118, 2009.

Xu, C., Ma, Y. M., Panday, A., Cong, Z. Y., Yang, K., Zhu, Z. K., Wang, J. M., Amatya, P. M., and Zhao, L.: Similarities and differences of aerosol optical properties between southern and north- 
ern sides of the Himalayas, Atmos. Chem. Phys., 14, 3133-3149, doi:10.5194/acp-14-3133-2014, 2014.

Yang, Y., Di Girolamo, L., and Mazzoni, D.: Selection of the automated thresholding algorithm for the Multi-angle Imaging SpectroRadiometer Radiometric Camera-by-Camera Cloud Mask over land, Remote Sens. Environ., 107, 159-171, doi:10.1016/j.rse.2006.05.020, 2007.

Yao, T., Thompson, L., Yang, W., Yu, W., Gao, Y., Guo, X., Yang, X., Duan, K., Zhao, H., and Xu, B.: Different glacier status with atmospheric circulations in Tibetan Plateau and surroundings, Nature Climate Change, 2, 663-667, 2012.

Yao, T., Masson-Delmotte, V., Gao, J., Yu, W., Yang, X., Risi, C., Sturm, C., Werner, M., Zhao, H., He, Y., Ren, W., Tian, L., Shi, C., and Hou, S.: A review of climatic controls on $\delta^{18} \mathrm{O}$ in precipitation over the Tibetan Plateau: Observations and simulations, Rev. Geophys., 51, 525-548, doi:10.1002/rog.20023, 2013.
Zhang, Q., Streets, D. G., Carmichael, G. R., He, K. B., Huo, H., Kannari, A., Klimont, Z., Park, I. S., Reddy, S., Fu, J. S., Chen, D., Duan, L., Lei, Y., Wang, L. T., and Yao, Z. L.: Asian emissions in 2006 for the NASA INTEX-B mission, Atmos. Chem. Phys., 9, 5131-5153, doi:10.5194/acp-9-5131-2009, 2009.

Zhang, R., Wang, H., Qian, Y., Rasch, P. J., Easter, R. C., Ma, P.L., Singh, B., Huang, J., and Fu, Q.: Quantifying sources, transport, deposition, and radiative forcing of black carbon over the Himalayas and Tibetan Plateau, Atmos. Chem. Phys., 15, 62056223, doi:10.5194/acp-15-6205-2015, 2015.

Zhang, X. Y., Gong, S. L., Shen, Z. X., Mei, F. M., Xi, X. X., Liu, L. C., Zhou, Z. J., Wang, D., Wang, Y. Q., and Cheng, Y.: Characterization of soil dust aerosol in China and its transport and distribution during 2001 ACE-Asia: 1. Network observations, J. Geophys. Res.-Atmos., 108, 4261, doi:10.1029/2002JD002632, 2003. 